\title{
molecules
}

ISSN 1420-3049

(C) 2007 by MDPI

www.mdpi.org/molecules

Review

\section{Flavonoids and Strigolactones in Root Exudates as Signals in Symbiotic and Pathogenic Plant-Fungus Interactions}

\author{
Siegrid Steinkellner ${ }^{1, *}$, Venasius Lendzemo ${ }^{2}$, Ingrid Langer ${ }^{3}$, Peter Schweiger ${ }^{3}$, Thanasan \\ Khaosaad ${ }^{1}$, Jean-Patrick Toussaint ${ }^{4}$ and Horst Vierheilig ${ }^{1}$ \\ ${ }^{1}$ Institut für Pflanzenschutz, Department für Angewandte Pflanzenwissenschaften und \\ Pflanzen-biotechnologie, Universität für Bodenkultur Wien, Peter Jordan-Straße 82, A-1190 Wien, \\ Austria; E-mail: siegrid.steinkellner@boku.ac.at, thanasan.khaosaad@boku.ac.at; \\ horst.vierheilig@boku.ac.at \\ ${ }^{2}$ Institute of Agricultural Research for Development, Maroua, Cameroon; E-mail: \\ vlendzemo@hotmail.com \\ ${ }^{3}$ Institut für Bodenforschung, Department für Wald- und Bodenwissenschaften, Universität für \\ Bodenkultur Wien, Peter Jordan-Straße 82, A-1190 Wien, Austria; E-mail: ingrid.langer@boku.ac.at; \\ peter.schweiger@boku.ac.at \\ ${ }^{4}$ School of Earth and Environmental Sciences, The University of Adelaide, Adelaide, Australia; \\ E-mail: jeanpatrick.toussaint@adelaide.edu.au
}

* Authors to whom correspondence should be addressed; E-mail: siegrid.steinkellner@boku.ac.at Received: 29 May 2007; in revised form: 20 June 2007 / Accepted: 3 July 2007 / Published: 5 July 2007

\begin{abstract}
Secondary plant compounds are important signals in several symbiotic and pathogenic plant-microbe interactions. The present review is limited to two groups of secondary plant compounds, flavonoids and strigolactones, which have been reported in root exudates. Data on flavonoids as signaling compounds are available from several symbiotic and pathogenic plant-microbe interactions, whereas only recently initial data on the role of strigolactones as plant signals in the arbuscular mycorrhizal symbiosis have been reported. Data from other plant-microbe interactions and strigolactones are not available yet. In the present article we are focusing on flavonoids in plant-fungal interactions such as the arbuscular mycorrhizal (AM) association and the signaling between different Fusarium species and plants. Moreover the role of strigolactones in the
\end{abstract}


AM association is discussed and new data on the effect of strigolactones on fungi, apart from arbuscular mycorrhizal fungi (AMF), are provided.

Keywords: Arbuscular mycorrhiza, flavonoids, Fusarium, root exudates, strigolactones, striga, orobanche, signaling.

\section{Contents}

1. Introduction

2. Flavonoids

2.1. Flavonoids and AMF

2.2. Flavonoids and pathogenic fungi

3. Strigolactones

3.1. Strigolactones and AMF

3.2. Strigolactones, Fusarium sp. and other fungi

4. Conclusions

\section{Introduction}

Plant roots release a wide range of compounds which are involved in complex communication processes in the rhizosphere. These compounds include sugars, polysaccharides, amino acids, aliphatic acids, aromatic acids, fatty acids, sterols, phenolics, enzymes, vitamins, plant growth regulators and other secondary metabolites [1,2,3]. Although a multitude of soilborne fungi are known to respond to root exudates, an identification of all plant derived signals is still missing. There is no doubt that sugars and amino acids are potential fungal stimuli [4], however, our knowledge on secondary metabolites, which trigger microbe responses in the rhizosphere, is relatively limited [5,6].

In the present review we focus on two groups of secondary compounds in root exudates which have been reported as key signaling molecules for plant microbe interactions in the soil. Flavonoids are known from a number of plant (primarily legumes) interactions with microbes such as nitrogen fixing rhizobium, arbuscular mycorrhizal fungi, Fusarium sp. as signaling compounds and strigolactones, known so far as germination inducers of seeds of the parasitic plants Striga and Orobanche, very recently have been suggested to play a key role during the establishment of the AM symbiosis. The involvement in signaling of these two compound groups in the symbiotic arbuscular mycorrhizal fungi-plant and in pathogenic fungi-plant interactions is discussed.

\section{Flavonoids}

Apart from other compounds in root exudates, flavonoids (Figure 1) are known as key signaling compounds in a number of plant-microbe interactions e.g. in the symbiotic rhizobium-legume interaction. Flavonoids act as chemoattractants for rhizobial bacteria and as specific inducers of rhizobial nodulation genes (nod-genes), which are involved in the synthesis of lipo- 
chitooligosaccharide signals, called Nod factors (reviewed in [7]). In roots of legumes Nod factors induce the accumulation of flavonoids resulting in the secretion of more flavonoids by the root, which further stimulate the production of Nod factors by the bacteria [8-11]. Apart from their function in the rhizobium-legume interaction, flavonoids also act as signaling compounds in the AM symbiosis and in different plant-soil pathogen interactions.

Figure 1. Chemical structures of the different groups of flavonoid compounds.<smiles>O=c1c(O)c(-c2ccc(O)cc2)oc2cc(O)cc(O)c12</smiles>

flavonols<smiles>O=C1C[C@@H](c2ccc(O)cc2)Oc2cc(O)cc(O)c21</smiles>

flavanones<smiles>O=c1cc(-c2ccc(O)cc2)oc2cc(O)cc(O)c12</smiles>

flavones<smiles>O=c1c(-c2ccc(O)cc2)coc2cc(O)cc(O)c12</smiles>

isoflavones

\subsection{Flavonoids and AMF}

Similar to the rhizobium-legume interaction in the AMF - host interaction, root exudates play an important role at the beginning of a signal exchange chain between the host plant and the AMF. As flavonoids are present in root exudates, their involvement in the signaling of the host plant-AMF interaction has been suggested. Abundant data are available on the effect of flavonoids on hyphal growth, hyphal differentiation and root colonization (for more detailed information see reviews $[12,13]$. A number of flavonoids exhibit a clear stimulatory effect on AMF hyphal growth and this effect seems to depend on the chemical structure of the compound [14-16]. Interestingly the stimulatory effect of the flavonoids has been shown to be even more pronounced in presence of $\mathrm{CO}_{2}$ at concentrations similar to those found in the rhizosphere [14,15,17]. In most recent studies it has been reported that during pre-symbiotic growth and when applied to plants inoculated with AMF, flavonoids exhibit an AMF fungal genus- and species specific effect [18-20]. 
Once plants are colonized by AMF the pattern of flavonoids is dramatically changed (see reviews [12, 13]). Interestingly, similar to the effect of flavonoids on different pre-symbiotic stages of AMF [18-20], the alterations of the flavonoid pattern in roots produced by different AMFs also exhibit a certain AMF fungal genus- and species specificity [21,22]. Larose et al. [22] and Harrison and Dixon [23] linked the alterations of the flavonoid pattern in mycorrhizal roots to the developmental stage of the AM symbiosis. Whereas during root penetration and the early establishment of AMF intermediate levels of a number of flavonoids are detected in roots, at a later stage of root colonization characterized among others by abundant collapsed arbuscules, high levels of flavonoids such as the phytoalexin medicarpin have been reported [22]. Interestingly the levels of some flavonoids are not only altered in mycorrhizal roots but also in non-mycorrhizal roots of a mycorrhizal plant indicating a systemic regulation of the flavonoid accumulation [24].

To summarize, as different flavonoids can be found in different plant groups, their roles as general signaling compounds during the establishment of the AM symbiosis are questionable [25], however, there are several indications that at a later stage of the AM association; when the AMF is well established, changes of the flavonoid pattern play a regulatory role [22, 24]. Only recently, potential general AM signaling compounds at the pre-symbiotic stage of the AM interaction have been identified in root exudates (see "Strigolactones”).

\subsection{Flavonoids and pathogenic fungi}

Responses of soilborne pathogens to flavonoids are primarily known for the fungal like oomycetes, such as chemotaxis by motile zoospores of Phytophthora sojae [26-28]. These organisms show physiological and morphological similarities to fungi but are phylogenetically different [29]. Apart from this there is only limited information available about flavonoids as signaling compounds for fungal pathogens of legumes [30,31]. Informations about possible effects of flavonoids in root exudates on root infecting/colonizing fungi of non-legume plants, however, are scarce.

As shown by Ruan et al. [30] various flavonoids which occur in root exudates of legumes exhibit a strong stimulatory effect on the macroconidia germination of the pea and bean pathogen Fusarium solani. Testing F. solani f.sp. pisi (pea pathogen) and f.sp. phaseoli (bean pathogen) they found highly stimulatory flavonoids. Ruan et al. [30] found, that inhibitors of cAMP-dependent protein kinase suppressed flavonoid responsive germination, while nutrient responsive germination was not affected. Thus, they hypothesized, that flavonoids present in root exudates of legumes stimulated the germination of fungi by a different mechanism that those of nutrients. A study of Bagga and Straney [31] reinforced the hypothesis that the macroconidia germination of F. solani seems to utilize the cAMP signaling pathway.

Interestingly, Ruan et al. [30] found no flavonoid-responsive macroconidia germination for $F$. acuminatum, a pathogen on gramineous plants, and F. solani pathogenic on cucurbits. Steinkellner et al. [32] tested the effect of 12 flavonoids, representing different classes of flavonoids, on microconidia germination of $F$. oxysporum f.sp. lycopersici ( $F o l)$, the pathogen causing tomato wilt. Applying the flavonoids at five different concentrations, they found no significant effect microconidia germination. In contrast to these authors [30], who found that flavonoids provide a certain level of host specific 
recognition among F. solani pathogenic on legumes, according to Steinkellner et al. [32] flavonoids seems not to be specific stimulating compounds to $F$. oxysporum pathogenic on tomato.

Comparing the germination activity of F. solani f.sp. pisi in root exudates, Straney et al. [33] found the highest macroconidia germination in pea exudates and a partial stimulation in bean exudates, whereas soybean and non-legume exudates did not display a stimulating activity. This effect seems to be host specific and linked with the presence or absence of flavonoids in the specific root exudates as known so far, especially as the germination activity did not correlate with the nutrient level. This specificity to root exudates of the host apparently is no general characteristic for other Fusarium species. Investigating the highly specific tomato pathogen Fol, Steinkellner et al. [34] recently found that not only tomato root exudates but also root exudates of Fol-non-host plants, such as sweet pepper, bean, barley, tobacco and cucumber, stimulated microconidia germination. These results suggest that Fol germination-stimulating-signals not only occur in root exudates of the host tomato but are general signals in root exudates [34].

Another function of flavonoids on fungal root pathogens has been documented for F. oxysporum $\mathrm{f}$. sp. dianthi. Interestingly, Curir et al. [35] isolated a kaempferide triglycoside in carnation stems and roots, involved in resistance of carnation to $F$. oxysporum $\mathrm{f}$. sp. dianthi. There is evidence to suggest that this flavonol functions as typical phytoalexin, responsive to $F$. oxysporum pathogenic to carnation [36].

\section{Strigolactones}

Striga and Orobanche are weeds which can parasitize a number of important crop plants and drastically lower yields. Strigolactones (Figure 2), a group of sesquiterpene lactones, are exuded by roots and stimulate seed germination of Striga and Orobanche and are present in root exudates in extremely low concentrations [37]. These Striga and Orobanche seed stimulating compounds are highly instable and have been detected not only in root exudates of host plants for these parasitic plants, but also in root exudates of non-host plants from different plant families (see Table 1).

Figure 2. Chemical structure of the synthetic strigolactone analogue GR24.

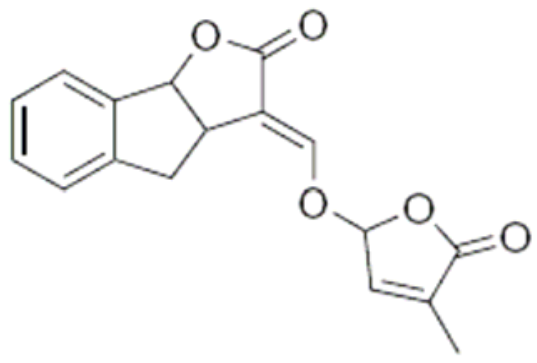


Table 1. Overview on plants were information is available on the presence of strigolactones in root exudates ${ }^{(1)}$, on the presence of compounds in root exudates exhibiting a stimulatory effect on seed germination of Striga/ Orobanche ${ }^{(2)}$ and on the presence of compounds in root exudates stimulating hyphal branching of AMF ${ }^{(3)}$.

\begin{tabular}{|c|c|c|c|c|c|c|}
\hline Family & $\begin{array}{c}\text { Plant } \\
\text { species }\end{array}$ & $\begin{array}{c}\text { Host for } \\
\text { Striga } \\
\text { and/or } \\
\text { Orobanche }\end{array}$ & $\begin{array}{l}\text { Strigolact. } \\
\text { detected in } \\
\text { root } \\
\text { exudates } \\
\text { (1) }\end{array}$ & $\begin{array}{c}\text { Root } \\
\text { exudates } \\
\text { stimulate } \\
\text { Striga/ Orob. } \\
\text { germinat. }^{(2)}\end{array}$ & $\begin{array}{c}\text { Root } \\
\text { exudat. } \\
\text { initiate } \\
\text { branching } \\
\text { of AMF }{ }^{(3)}\end{array}$ & Reference \\
\hline Alliaceae & Onion & & & Orob. & & 2) [38] \\
\hline Apiaceae & Celery & & & Orob. & & 2) [39] \\
\hline \multirow[t]{2}{*}{ Asteraceae } & Lettuce & Orobanche & & Orob. & & 2) $[39,97]$ \\
\hline & Sunflower & Orobanche & & Orob. & & 2) $[38,39]$ \\
\hline \multirow[t]{3}{*}{ Brassicaceae } & $\begin{array}{l}\text { Arabidopsis } \\
\text { thaliana }\end{array}$ & AM nonhost & & Orob. & no & $\begin{array}{l}\text { 2) }[40,41] \\
\text { 3) }[42]\end{array}$ \\
\hline & Rapeseed & AM nonhost & & Orob. & no & $\begin{array}{l}\text { 2) }[43] \\
\text { 3) }[42]\end{array}$ \\
\hline & Cabbage & AM nonhost & & Orob. & no & $\begin{array}{l}\text { 2) }[44] \\
\text { 3) }[42] \\
\end{array}$ \\
\hline Chenopodiaceae & Sugar beet & AM nonhost & & & no & 3) $[42,45]$ \\
\hline Cucurbitaceae & Cucumber & & & Orob. & & 2) $[38,39]$ \\
\hline \multirow[t]{7}{*}{ Gramineae } & Maize & Striga & Yes & Strig.+Orob. & Yes & $\begin{array}{l}\text { 1) }[46] \\
\text { 2) }[38,39,47] \\
\text { 3) }[42]\end{array}$ \\
\hline & Sorghum & Striga & Yes & Strig.* +Orob & Yes & $\begin{array}{l}\text { 1) }[46-48] \\
\text { 2) }[47,49 *] \\
\text { 3) }[42,50]\end{array}$ \\
\hline & Millet & Striga & Yes & Orob. & & $\begin{array}{l}\text { 1) }[46,47] \\
\text { 2) }[47]\end{array}$ \\
\hline & Barley & & & Strig.+Orob. & & 2) $[39,51]$ \\
\hline & Oat & & & Orob. & & 2) [39] \\
\hline & Wheat & & & Orob. & & 2) [39] \\
\hline & Ryegrass & & & Orob. & & 2) [39] \\
\hline Lamiaceae & Basil & & & Orob. & & 2) [38] \\
\hline \multirow[t]{4}{*}{ Leguminoseae } & Pea & Orobanche & & Orob. & Yes & $\begin{array}{l}\text { 2) }[53] \\
\text { 3) }[42]\end{array}$ \\
\hline & $\begin{array}{l}\text { Medicago } \\
\text { truncatula }\end{array}$ & & & Orob. & Yes & $\begin{array}{l}\text { 2) }[54] \\
\text { 3) }[42]\end{array}$ \\
\hline & Alfalfa & & & Orob. & Yes & $\begin{array}{l}\text { 2) }[39] \\
\text { 3) }[42] \\
\end{array}$ \\
\hline & Red clover & Orobanche & Yes & Orob. & & $\begin{array}{l}\text { 1) }[55,56] \\
\text { 2) }[39]\end{array}$ \\
\hline
\end{tabular}


Table 1. Cont.

\begin{tabular}{|c|c|c|c|c|c|c|}
\hline \multirow[t]{3}{*}{ Leguminoseae } & Cowpea & Striga & Yes & Strig. & & $\begin{array}{l}\text { 1) }[57] \\
\text { 2) }[58]\end{array}$ \\
\hline & Soybean & & Yes & Strig.+Orob. & & $\begin{array}{l}\text { 1) }[59] \\
\text { 2) }[38,60,61]\end{array}$ \\
\hline & $\begin{array}{l}\text { Lotus } \\
\text { japonicus }\end{array}$ & & Yes & & & 1) [59] \\
\hline Linaceae & Flax & & & Orob. & & 2) [39] \\
\hline Malvaceae & Cotton & & Yes & Strig.+Orob. & & $\begin{array}{l}\text { 1) }[56,62] \\
\text { 2) }[56]\end{array}$ \\
\hline \multirow[t]{2}{*}{ Solanaceae } & Tobacco & $\begin{array}{l}\text { Striga/ } \\
\text { Orobanche }\end{array}$ & Yes & Strig.+Orob. & Yes & $\begin{array}{l}\text { 2) }[41,63] \\
\text { 3) }[42]\end{array}$ \\
\hline & Tomato & Orobanche & Yes & Orob. & Yes & $\begin{array}{l}\text { 1) }[64] \\
\text { 2) }[38,39,65] \\
\text { 3) }[42,45]\end{array}$ \\
\hline Tropaeolaceae & $\begin{array}{l}\text { Tropaelum } \\
\text { majus }\end{array}$ & & & Orob. & & 2) [39] \\
\hline
\end{tabular}

(1) (2) (3) Blanks in columns indicate no available information

${ }^{(2)}$ Indication of only one plant indicate no available information for the other plant

*reduced activity when from mycorrhizal plants;

\subsection{Strigolactones and AMF}

Apart from affecting hyphal growth, compounds released by host roots have been reported to induce branching of AMF hyphae [66-70]. Hyphal branching of AMF has been suggested as one of the events in host root recognition that precedes successful root colonization [42,45,71], as through the branching response "...the probability of encounter with a site on the root suitable for colonization..." [45] is increased. Active branching signals have been reported from a wide range of AM host plants such as carrot, tobacco, corn, sorghum, pea and tomato (Table 1). Recently, Tamasloukht et al. [72] determined the time course of action of the root-exuded branching factor. Application of the branching factor to a hyphae resulted in gene activation in Gigaspora rosea after $0.5-1 \mathrm{~h}$, in alterations at the physiological level after 1.5-3h, and the beginning of hyphal branching could be observed after 5h.

A hyphal branching effect has been reported for a number of flavonoids [16,18,19,73,74], however, as the flavonoids inducing branching can only be found in a limited number of plants, their role as general signaling compounds for hyphal branching as a pre-requisite for a successful AM root colonization seems questionable.

A number of studies attempted to identify the branching factor in root exudates of AM host plants [42,45,75,76], however, only recently strigolactones have been identified as the AMF hyphal branching factor in root exudates of the AM host plant Lotus japonicus [59]. More effects of strigolactones and AMF have been reported on a physiological level. In Glomus intraradices and Glomus claroideum, spore germination was stimulated in the presence of strigolactones and in $G$. rosea the mitochondrial shape and movement were altered and their density in the fungal cell increased [50]. Akiyama et al. [77] hypothesized that strigolactones are not only involved as primary 
signals for AMF hyphal branching but also as signals for the reported directional growth of AMF towards roots [78,79], however, no data on this effect are available yet.

As strigolactones are present in the exudates of plants from diverse taxa (see Table 1) it has been proposed that they are general essential signaling compounds for the establishment of the AM symbiosis [77]. This hypothesis has been strengthened in a recent paper by Gomez-Roldan and coworkers [80]. They started from the hypothesis of Matusova et al. [52] that strigolactones are derived from the carotenoid pathway. Thus, provided that strigolactones are essential signals for the establishment of the AM association, alterations of the carotenoid metabolism could affect the AMFplant interaction. This hypothesis was tested with maize mutants with a defect in the carotenoid pathway and with maize plants treated with an inhibitor of the carotenoid pathway. In both treatments root colonization by $G$. rosea was reduced, indicating that the levels of important signaling compounds were reduced. Most interestingly, the application of the strigolactone analogue GR24 to the inoculated mutant and inhibitor-treated plants restored the AM root colonization to similar levels as in the control plants [80].

However, these results give rise to a new question. Is the recovery of the AM root colonization in these maize plants after GR24 application due to a stimulation of the AMF spore germination or due to an enhanced branching? It has been reported before that strigolactones stimulate spore germination of AMF [50], thus, in the above mentioned experiment enhanced spore germination could be responsible for the recovery of AM root colonization.

The restored AM root colonization also could be due to the effect of GR24 on hyphal branching. Hyphal branching of AMF has been reported in the vicinity of roots of host plants and has been suggested as an important step that precedes successful root colonization [66-70]. Application of GR24 to the growth substrate of plants as reported by Gomez-Roldan et al. [80] should result in profuse branching of the AMF hyphae in the substrate independent of the presence or absence of roots. This could mean that branching by itself is an important step in the AM-plant interaction, but that branching does not have to occur close to the roots of a host plant.

Recent data also suggest a role of strigolactones at a later stage of the AMF-plant interaction, when the fungus is already established in the root. In several studies it has been demonstrated that once plants are mycorrhizal, further root colonization by AMF is reduced compared to colonization of nonmycorrhizal plants [24,81-86]. Looking at these observations it is tempting to speculate that due to altered levels of strigolactones in root exudates of mycorrhizal plants further root colonization by AMF is affected.

In several studies it has been reported that the attachment and the emergence of Striga is reduced in mycorrhizal sorghum and maize [49,86-89] and Matusova et al. [52] hypothesized that mycorrhization might alter the level of strigolactones and thus affect the seed-germination of parasitic plants through a down-regulation of the mycorrhizal branching factor formation. Data obtained on the effect of root exudates from mycorrhizal and non-mycorrhizal plants on Striga seed germination and AMF branching strengthen this hypothesis. Root exudates of mycorrhizal sorghum and maize induced a lower Striga seed germination than root exudates of the non-mycorrhizal control plants [49,90] and root exudates of mycorrhizal cucumber plants induced a lower in vitro branching of an AMF than exudates of non-mycorrhizal cucumber plants [91,92]. 
The hypothesis of branching factor(s) in root exudates as a regulating mechanism for root colonization is strengthened further when looking at the effect of root exudates from plants with high P-levels on hyphal branching. It has been reported that at high P-levels in roots the strigolactone production is reduced [93,94]. Hyphal branching in the presence of root exudates from low P-plants has been reported [42,45,75,76]. Interestingly, when root exudates were collected from high P-plants a stimulating effect on branching could not be observed [42,45]. These data indicate that in plants already colonized by AMF or in plants with high P-levels a reduced root colonization is possibly linked with reduced levels of strigolactone in root exudates.

Strigolactones present in root exudates and inducing hyphal branching of AMF have been suggested as important plant recognitions signals for AMF [50,59,77,80]. However, some data on the effect of root exudates on Orobanche seed germination and AMF hyphal branching due to the presence of strigolactones in root exudates still seem contradictory. Arabidopsis thaliana, rape and cabbage (Brassicacea) and sugar beet (Chenopodiaceae) are known to be AM non-host plants [96]. Interestingly none of the root exudates of these plants (Table 1; [42,45]) showed a hyphal branching activity on AMF indicating the absence of a branching factor in these exudates, however, root exudates of Arabidopsis thaliana, rape and cabbage stimulated the germination of Orobanche seeds $[40,41,43,44]$. Comparing the stimulatory effect of root exudates of carrot, tobacco and $A$. thaliana on Orobanche seeds, Westwood [41] reported a reduced level of seed stimulating compounds in root exudates of $A$. thaliana. In our context this could mean that hyphal branching is less sensitive to strigolactones than germination of parasitic weeds of the Orobanchaceae and the Scrophulariaceae. Another explanation could be that specific seed stimulants are secreted by plants of the Brassicaceae which do not exhibit a hyphal branching activity on AMF.

\subsection{Strigolactones, Fusarium sp. and other fungi}

Strigolactones have been reported to be present in the root exudates of a wide range of different plants (see Table 1), thus it would not be surprising that these compounds do not only act as signals for AMF but also for other fungi (e.g. soilborne fungi). To our knowledge no data have been available yet on the effect of strigolactones on other fungi apart from AMF. We tested the effect of the strigolactone analogue GR24, which is known to induce hyphal branching of AMF [59], on fungi from four different groups (Table 2): ectomycorrhizal fungi, beneficial fungi such as Trichoderma and Piriformospora indica, soil-borne pathogens and the two shoot pathogens Botrytis cinerea and Cladosporium sp.. With none of the tested fungi any alterations of the branching pattern due to the application of GR24 could be observed.

Moreover, we tested the effect of strigolactones on the microconidia germination of Fol. Most recently, it has been reported that strigolactones stimulate the spore germination of AMF [50]; however, we found that they do not affect the microconidia germination of Fol (Steinkellner and Mammerler unpublished results). These preliminary data indicate that strigolactones are specific signals for AMF but not general plant signals for fungi. However, further studies are needed to confirm this hypothesis. 
Table 2. Effect of the strigolactone analogue GR24 on hyphal branching of different fungi.

\begin{tabular}{|l|l|l|l|c|}
\hline \multirow{4}{*}{ Fungal group } & \multicolumn{1}{|c|}{ Fungus } & \multicolumn{1}{|c|}{ Growth medium } & \multicolumn{1}{c|}{$\begin{array}{c}\text { Observation } \\
\text { after } \\
\text { treatment }\end{array}$} & $\begin{array}{c}\text { Effect on } \\
\text { branching }\end{array}$ \\
\hline Ectomycorrhiza & Paxillus involutus & $\begin{array}{l}1 / 2 \text { modified Melin } \\
\text { Norkans medium }\end{array}$ & $22,24 \mathrm{~h}$ & No \\
\cline { 2 - 5 } & Laccaria bicolor & $\begin{array}{l}1 / 2 \text { modified Melin } \\
\text { Norkans medium }\end{array}$ & $22 \mathrm{~h}$ & No \\
\cline { 2 - 5 } & Amanita muscaria & $\begin{array}{l}1 / 2 \text { modified Melin } \\
\text { Norkans medium }\end{array}$ & $22 \mathrm{~h}$ & No \\
\cline { 2 - 5 } & Cenococcum geophilum & $\begin{array}{l}1 / 2 \text { modified Melin } \\
\text { Norkans medium }\end{array}$ & $16 \mathrm{~h}$ & No \\
\hline \multirow{3}{*}{$\begin{array}{l}\text { Beneficial fungi-borne } \\
\text { pathogen }\end{array}$} & Trichoderma & Water agar & $16 \mathrm{~h}$ & No \\
\cline { 2 - 5 } & Piriformospora indica & Nutrient agar & $18 \mathrm{~h}$ & No \\
\cline { 2 - 5 } & Rhizoctonia solani & $\begin{array}{l}\text { Water agar } \\
\text { Potato dextrose agar }\end{array}$ & $6,16,40 \mathrm{~h}$ & No \\
\cline { 2 - 5 } & Fusarium oxysporum & $\begin{array}{l}\text { Water agar } \\
\text { Potato dextrose agar }\end{array}$ & $16,38 \mathrm{~h}$ & No \\
\cline { 2 - 5 } & Verticillium dahliae & $\begin{array}{l}\text { Water agar } \\
\text { Potato dextrose agar }\end{array}$ & $23 \mathrm{~h}$ & No \\
\hline \multirow{3}{*}{$\begin{array}{l}\text { Pathogen on } \\
\text { aerial plant parts }\end{array}$} & Botrytis cinerea & Water agar & $23 \mathrm{~h}$ & No \\
\cline { 2 - 5 } & Cladosporium sp. & Water agar & $6,30 \mathrm{~h}$ & \\
\hline
\end{tabular}

Experimental set-up: About 1.5-2 $\mathrm{mm}$ in front of the colony growing in a petri dish small holes (approx. $2 \mathrm{~mm}$ diam.) were punched with a plastic pipette and the content was removed by suction. To the holes $\mathrm{H}_{2} \mathrm{O}$ or GR24 (which had been diluted in acetone), or the same acetone concentration as in the GR24 treatment $(12 \mu \mathrm{L})$ were applied (for further details see Nagahashi and Douds [45]). Before observation with a microscope, a lactophenol cotton blue solution was sprayed onto the mycelium in the petri dish to obtain a better contrast. To assure the use of an active GR24 solution, the GR24 solution $(0.1 \mathrm{mg} / \mathrm{L}$ which was before diluted in $0.1 \mathrm{~mL}$ acetone) was tested on the germination of Striga hermonthica seeds before. Growth conditions of fungi: All tested fungi were grown in the dark at $24{ }^{\circ} \mathrm{C}$. Piriformospora indica was kindly provided by Katarzyna Turnau/ Kraków/Poland.

\section{Conclusions}

Flavonoids in root exudates are known as signaling compounds in a number of pathogenic and symbiotic plant-microbe interactions; however, their importance seems to depend highly on the specific interaction. Whereas these compounds are known as key signals in the rhizobium-legume interaction, despite their effect on AMF spore germination, hyphal growth and differentiation, their effect on AM root colonization and their altered accumulation pattern in mycorrhizal roots, an essential role of flavonoids for the outcome of the AM symbiosis has been questioned [25]. From all the data accumulated on flavonoids and AMF a general role of flavonoids as signals at an early stage of the interaction, during the establishment of the AM association, seems unlikely, however, a 
potential role in the regulation of mycorrhization, once the AMF has colonized the host root, can not be excluded.

In several Fusarium-plant interactions an effect of flavonoids on micro- and macroconidia germination has been reported, however, nearly no data are available yet on hyphal growth and the role of flavonoids during infection. Moreover, to our knowledge scarce data are available about alterations of flavonoid level in plants infected by Fusarium. Thus, further studies are needed to elucidate their exact role in this interaction.

Striglactones only recently have been identified as important signals in the AMF-plant interaction and thus are "hot issues" in mycorrhizal research. To our knowledge no data are available yet about their implication as signaling compounds in other plant-microbe interactions. Our preliminary data with a number of different fungi indicate that strigolactones are specific signaling compounds for the AMF-plant interaction and are not involved in similar signaling events in other plant-fungus interactions, however, due to their nearly ubiquitous presence in the root exudates of plants it would not make wonder to find the involvement of these compounds in the signaling of other plant interactions. We are convinced that in the near future there will be some new and exciting data in the field of strigolactones and plant interactions.

\section{Acknowledgements}

This work was partially funded by a grant of the Thai government to TK and the "Netherlands Foundation for the Advancement of Tropical Research" supported the stay of VL in Vienna/Austria. We kindly thank Ao.Prof. Dr. Franz Hadacek for helpful advice.

\section{References and Notes}

1. Neumann, G.; Römheld, V. The release of root exudates as affected by the plant physiological status. In The Rhizosphere: Biochemistry and organic substances at the soil-plant interface. Pinton, R.; Varanini, Z., Nannipieri, P., Eds.; Marcel Dekker: New York, 2001.

2. Uren, N. C. Types, amounts, and possible functions of compounds released into the rhizosphere by soil-grown plants. In The Rhizosphere: Biochemistry and organic substances at the soil-plant interface. Pinton, R.; Varanini, Z., Nannipieri, P., Eds.; Marcel Dekker: New York, 2000; pp. 1940.

3. Bertin C.; Yang X.; Weston, L. A. The role of root exudates and allelochemicals in the rhizosphere. Plant Soil 2003, 256, 67-83.

4. Nelson, E. B.; Hsu, J. S. T. Nutritional factors affecting responses of sporangia of Pythium ultimum to germination stimulants. Phytopathology 1994, 84, 677-683.

5. Nelson, E.B. Exudate molecules initiating fungal response to seed and roots. In The rhizosphere and plant growth. Keister, D. L.; Cregan, P. B., Eds.; Kluwer: Dortrecht, 1991; pp. 197-209.

6. Bais, H. P.; Weir, T. L.; Perry, L. G.; Gilroy, S.; Vivanco, J. M. The role of root exudates in rhizosphere interactions with plants and other organisms. Ann. Rev. Plant Biology 2006, 57, 233266. 
7. Perret, X.; Staehelin, C.; Broughton, W. J. Molecular basis of symbiotic promiscuity. Microbiol. Mol. Biol. Rev. 2000, 64, 180-201.

8. Recourt, K.; Van Tunen, A. J.; Mur, L. A.; Van Brussel, A. A. N.; Lugtenberg, B.; Kijne, J. W. Activation of flavonoid biosynthesis in roots of Vicia sativa subsp. nigra plants by inoculation with Rhizobium leguminosarum biovar viciae. Plant Mol. Biol. 1992, 19, 411-420.

9. Dakora, F. D.; Joseph, C. M.; Phillips, D. A. Alfalfa (Medicago sativa L.) root exudates contain isoflavonoids in the presence of Rhizobium meliloti. Plant Physiol. 1993, 101, 819-824.

10. Schmidt, P. E.; Broughton, W. J.; Werner, D. Nod factors of Bradyrhizobium japonicum and Rhizobium sp. NGR234 induce flavonoid accumulation in soybean root exudates. Mol. PlantMicrobe Interact. 1994, 7, 384-390.

11. Bolanos-Vasquez, M. C.; Werner, D. Effect of Rhizobium tropici, R. etli, and R. leguminosarum bv. phaseoli on nod gene-inducing flavonoids in root exudates of Phaseolus vulgaris. Mol. PlantMicrobe Interact. 1997, 10, 339-346.

12. Morandi, D. Occurrence of phytoalexins and phenolic compounds on endomycorrhizal interactions, and their potential role in biological control. Plant Soil 1996, 185, 241-251.

13. Vierheilig, H.; Bago, B.; Albrecht, C.; Poulin, M.-P.; Piché, Y. Flavonoids and arbuscularmycorrhizal fungi. In Flavonoids in the Living System. Manthey, J.A.; Buslig, B. S., Eds.; Plenum Press: New York, 1998; pp. 9-33.

14. Bécard, G.; Douds, D. D.; Pfeffer, P. E. Extensive in vitro hyphal growth of vesicular-arbuscular mycorrhizal fungi in the presence of $\mathrm{CO}_{2}$ and flavonols. Appl. Environ. Microbiol. 1992, 68, 1260-1264.

15. Chabot, S.; Bel-Rhlid, R.; Chênevert, R.; Piché, Y. Hyphal growth promotion in vitro of the VA mycorrhizal fungus, Gigaspora margarita Becker \& Hall, by the activity of structurally specific flavonoids compounds under $\mathrm{CO}_{2}$-enriched conditions. New Phytol. 1992, 122, 461-467.

16. Scervino, J. M.; Ponce, M. A.; Erra-Bassels, R.; Vierheilig, H.; Ocampo, J. A.; Godeas, A. Glycosidation of apigenin results in a loss of activity on different growth parameters of arbuscular mycorrhizal fungi from the genus Glomus and Gigaspora. Soil Biol. Biochem. 2006, 38, 29192922.

17. Poulin, M.-J.; Bel-Rhlid, R.; Piché, Y.; Chênevert, R. Flavonoids released by carrot (Daucus carota) seedlings stimulate hyphal development of vesicular-arbuscular mycorrhizal fungi in the presence of optimal CO2 enrichment. J. Chem. Ecol. 1993, 19, 2317-2327.

18. Scervino, J. M.; Ponce, M. A.; Erra-Bassels, R.; Vierheilig, H.; Ocampo, J. A.; Godeas, A. Flavonoids exhibit fungal species and genus specific effects on the presymbiotic growth of Gigaspora and Glomus. Mycol. Res. 2005, 109, 789-794.

19. Scervino, J.M.; Ponce, M. A.; Erra-Bassels, R.; Vierheilig, H.; Ocampo, J.A.; Godeas, A. Flavonoids exclusively present in mycorrhizal roots of white clover exhibit different effects on arbuscular mycorrhizal fungi than flavonoids exclusively present in non-mycorrhizal roots of white clover. J. Plant Interact. 2005, 15, 22-30.

20. Scervino, J. M.; Ponce, M. A.; Erra-Bassels, R.; Vierheilig, H.; Ocampo, J. A.; Godeas, A. Arbuscular mycorrhizal colonization of tomato by Gigaspora and Glomus species in presence of roots flavonoids. J. Plant Physiol. 2005, 162, 625-633. 
21. Morandi, D.; Branzanti, B.; Gianinazzi-Pearson, V. Isoflavonoid accumulation in soybean roots infected with vesicular-arbuscular mycorrhizal fungi. Physiol. Plant Pathol. 1984, 24, 357-364.

22. Larose, G.; Chenevert, R.; Moutoglis, P.; Gagne, S.; Piché, Y.; Vierheilig, H. Flavonoid levels in roots of Medicago sativa are modulated by the developmental stage of the symbiosis and the root colonizing arbuscular mycorrhizal fungus. J. Plant Physiol. 2002, 159, 1329-1339.

23. Harrison, M.; Dixon, R. Isoflavonoid accumulation and expression of defense gene transcripts during the establishment of vesicular arbuscular mycorrhizal associations in roots of Medicago truncatula. Mol. Plant-Microbe Interact. 1993, 6, 643-659.

24. Catford, J. G.; Staehelin, C.; Larose, G.; Piché, Y.; Vierheilig, H. Systemically suppressed isoflavonoids and their stimulating effects on nodulation and mycorrhization in alfalfa split-root systems. Plant Soil 2006, 285, 257-266.

25. Bécard, G.; Taylor, L. P.; Douds, D. D.; Pfeffer, P. E.; Doner, L. W. Flavonoids are not necessary plant signal compounds in arbuscular mycorrhizal symbiosis. Mol. Plant-Microbe Interact. 1995, 8, 252-258.

26. Morris, P. F.; Ward, E. W. B. Chemoattraction of zoospores of the soybean pathogen, P. sojae, by isoflavones. Physiol. Mol. Plant Pathol. 1992, 40, 17-22.

27. Tyler, B. M.; Wu, M.; Wang, J.; Cheung, W.; Morris, P. F. Chemotactic preferences and strain variation in the response of Phytophthora sojae zoospores to host isoflavonones. Appl. Environ. Microbiol. 1996, 62, 2811-2817.

28. Morris, P. F.; Bone, E.; Tyler, B. M. Chemotropic and contact responses of Phytophthora sojae hyphae to soybean isoflavonoids and artificial substrates. Plant Physiol. 1998, 117, 1171-1178.

29. Hirsch, A. M.; Dietz Bauer, W.; Bird, D. M.; Cullimore, J.; Tyler, B.; Yoder, J. I. Molecular signals and receptors: controlling rhizosphere interactions between plants and other organisms. Ecology 2003, 84, 858-868.

30. Ruan, Y.; Kotraiah, V.; Straney, D. C. Flavonoids stimulate spore germination in Fusarium solani pathogenic on legumes in a manner sensitive to inhibitors of cAMP-dependent protein kinase. Mol. Plant Microb. Interact. 1995, 8, 929-938.

31. Bagga, S.; Straney, D. C. Modulation of cAMP and phosphodiesterase activity by flavonoids which induce spore germination of Nectria haematococa. Physiol. Molec. Plant Pathol. 2000, 56, 51-61.

32. Steinkellner, S.; Mammerler, R. Effect of flavonoids on the development of Fusarium oxysporum f. sp. lycopersici. J. Plant Interact. 2007, accepted

33. Straney, D., Khan, R.; Tan, R.; Bagga, S. Host recognition by pathogenic fungi through plant flavonoids. In Flavonoids in cell function. Buselig, B.; Manthey, J., Eds.; Kluwer Academic/Plenum Publishers: New York, 2002, pp. 9-22.

34. Steinkellner, S.; Mammerler, R.; Vierheilig, H. Microconidia germination of the tomato pathogen Fusarium oxysporum in the presence of root exudates. J. Plant Interact. 2005 1, 23-30.

35. Curir, P.; Dolci, M.; Lanzotti, V.; Taglialata-Scafati, O. Kaempferide triglycoside: a possible factor of resistance of carnation (Dianthus caryophyllus) to Fusarium oxysporum f. sp. dianthi. Phytochemistry 2001, 56, 717-721. 
36. Curir, P.; Dolci, M.; Galeotti, F. A phytoalexin-like flavonol involved in the carnation (Dianthus caryophyllus)-Fusarium oxysporum f.sp. dianthi pathosystem. J. Phytopathology 2005, 153, 6567.

37. Bouwmeester, H. J.; Roux, C.; Lopez-Raez, J. A.; Bécard, G. Rhizosphere communication of plants, parasitic plants and AM fungi. Trends Plant Sci. 2007, 12, 224-230.

38. Yoneyama, K.; Takeuchi, Y.; Yokota, T. Production of clover broomrape seed germination stimulants by red clover root requires nitrate but is inhibited by phosphate and ammonium. Physiol. Planta. 2001, 112, 25-30.

39. Ross, K. C.; Colquhoun, J. B.; Mallory-Smith, C. A. Small broom rape (Orobanche minor) germination and early development in response to plant species. Weed Sci. 2004, 52, 260-266.

40. Goldwasser, Y.; Yodder, J. I. Differential induction of Orobanche seed germination by Arabidopsis thaliana. Plant Sci. 2001, 160, 951-959.

41. Westwood, J. H. Characterization of the Orobanche-Arabidopsis system for studying parasite-host interactions. Weed Sci. 2000, 48, 742-748.

42. Buée, M.; Rossignol, M.; Jauneau, A.; Ranjeva, R.; Bécard, G. The pre-symbiotic growth of arbuscular mycorrhizal fungi is induced by a branching factor partially purified from plant root exudates. Mol. Plant-Microbe Interact. 2000, 13, 693-698.

43. Benharrat, H.; Boulet, C.; Veronesi, C.; Thalouarn, P. An overview of ongoing laboratory and field studies carried out on Orobanche ramosa: a pest for rape seed, hemp and tobacco. Phytoma 2003, 564, 24-26.

44. Jacobsohn, R.; Levy, D. Glyphosate for Orobanche control in various crops: problems and promises. In Proceedings of Workshop on Biology and Control of Orobanche; ter Borg, S.J., Ed.; Wageningen, The Netherlands, 1986; pp. 171-175.

45. Nagahashi, G.; Douds, D. D. Partial separation of root exudate components and their effects upon the growth of germinated spores of AM fungi. Mycol. Res. 2000, 104, 1453-1464.

46. Siame, B. A.; Weerasuriya, Y.; Wood, K.; Ejeta, G.; Butler, L. G. Isolation of strigol, a germination stimulant for Striga asiatica, from host plants. J. Agric. Food Chem. 1993, 41, 14861491.

47. Awad, A. A.; Sato, D.; Kusumoto, D.; Kamioka, H.; Takeuchi, Y.; Yoneyama, K. Characterization of strigolactones, germination stimulants for the root parasitic plants Striga and Orobanche, produced by maize, millet and sorghum. Plant Growth Regul. 2006, 48, 221-227.

48. Hauck, C.; Muller, S.; Schildknecht, H. A germination stimulant for parasitic flowering plants from Sorghum bicolor, a genuine host plant. J. Plant Physiol. 1992, 139, 474-478.

49. Lendzemo, V. W.; Kuyper, T. W.; Matusova, R.; Bouwmeester, H. J.; Van Ast, A. Colonization by arbuscular mycorrhizal fungi of sorghum leads to reduced germination and subsequent attachment and emergence of Striga hermonthica. Plant Signal. Behav. 2007, 2, 58-62.

50. Besserer, A.; Puech-Pàges, V.; Kiefer, P.; Gomez-Roldan, V.; Jauneau, A.; Roy, S.; Portais J. C.; Roux, C.; Bécard, G.; Séjalon-Delmas, N. Strigolactones stimulate arbuscular mycorrhizal fungi by activating mitochondria. PLoS Biology 2006, 4, 1239-1247.

51. Reda, F. Studies on striga host range and sorghum genotype screening for resistance. In Proceedings of the $5^{\text {th }}$ International Symposium on Parasitic Weeds, Nairobi, Kenya, 24-30 June, 
1991; Ransom, J. K.; Musselman, L. J.; Worsham, A. D., Eds.; CIMMYT: Nairobi, Kenya, 1991; pp. 545-550.

52. Matusova, R.; Rani, K.; Verstappen, F. W. A.; Franssen, M. C. R.; Beale, M. H.; Bouwmeester, H. J. The strigolactone germination stimulants of the plant-parasitic Striga and Orobanche spp. are derived from the carotenoid pathway. Plant Physiol. 2005, 139, 920-934.

53. Rubiales, D.; Pérez-de-Luque, A.; Cubero, J. I.; Sillero, J. C. Crenate broomrape (Orobanche crenata) infection in field pea cultivars. Crop Prot. 2003, 22, 865-872.

54. Rodriguez-Conde, M. F.; Moreno, M. T.; Cubero, J. I.; Rubiales, D. Characterization of the Orobanche-Medicago truncatula for studying early stages of the host-parasite interaction. Weed Res.2004, 44, 218-223.

55. Yokota, T.; Sakal, H.; Okuno, K.; Yoneyama, K.; Takeuchi, Y. Alectrol and Orobanchol, germination stimulants for Orobanche minor, from its host red clover. Phytochemistry 1998, 49, 1967-1973.

56. Sato, D.; Awad, A. A.; Takeuchi, Y.; Yoneyama, K. Confirmation and quantification of strigolactones, germination stimulants for root parasitic plants Striga and Orobanche, produced by cotton. 2005. Biosci. Biotechn. Biochem. 2005, 69, 98-102.

57. Müller, S.; Hauck, C.; Schildknecht, H. Germination stimulants produced by Vigna unguiculata Walp cv. Saunders Upright. J. Plant Growth Regul. 1992, 11, 77-84.

58. Berner, D. K.; Williams, O. A. Germination Stimulation of Striga gesnerioides seeds by hosts and nonhosts. Plant Dis. 1998, 82, 1242-1247.

59. Akiyama, K.; Matsuzaki, K.; Hayashi, H. Plant sesquiterpenes induce hyphal branching in arbuscular mycorrhizal fungi. Nature 2005, 435, 824-827.

60. Gbehounou, G.; Adango E. Trap crops of Striga hermonthica: in vitro identification and effectiveness in situ. Crop Prot. 2003, 22, 395-404.

61. Okpo, E. S.; Lagoke, S. T. O.; Ndahi, W. B.; Olufajo, O. O.; Tabo, R. Germination of witchweed (Striga hermonthica (Del.) Benth.) seeds in response to stimulation by root exudates of soybean (Glycine max L.). Global J. Agr. Sci. 2003, 2, 25-32.

62. Cook, C. E.; Whichard, L. P.; Wall, M. E.; Egley, G. H.; Coggon, P.; Luhan, P. A.; McPhail, A. T. Germination stimulants. 2. The structure of strigol - a potent seed germination stimulant for witchweed (Striga lutea Lour.). J. Am. Chem. Soc. 1972, 94, 6198-6199.

63. Gonzalez-Verdejo, C. I.; Barandiaran, X.; Moreno, M. T.; Cubero, J. I.; di Pietro, A. An improved axenic system for studying pre-infection development of the parasitic plant Orobanche ramosa. Ann. Bot. 2005, 96, 1121-1127.

64. Yoneyama. K.; Takeuchi, Y.; Sato, D.; Sekimoto, H.; Yokota, T. Determination and quantification of strigolactones. In Proceedings of the 8th International Parasitic Weed Symposium; Joel, D. M., Ed.; International Parasitic Plant Society: Amsterdam, 2004; p. 9.

65. Jain, R.; Foy, C. L. Nutrient effects on parasitism and germination of Egyptian broomrape (Orobanche aegyptiaca). Weed Techn. 1991, 6, 269-275.

66. Mosse, B.; Hepper C. M. Vesicular-arbuscular mycorrhizal infections in root organ cultures. Physiol. Plant. Pathol. 1975, 5, 215-223.

67. Powell, C. L. Development of mycorrhizal infection from Endogene spores and infected root fragments. Trans. Br. Mycol. Soc. 1976, 66, 439-445. 
68. Mosse, B. Some studies relating to "independent" growth of vesicular-arbuscular endophytes. Can. J. Bot. 1988, 66, 2533-2540.

69. Giovannetti, M.; Sbrana, C.; Avio, L.; Citernesi, A. S.; Logi, C. Differential hyphal morphogenesis in arbuscular mycorrhizal fungi during pre-infection stages. New Phytol. 1993, 125, 587-594.

70. Giovannetti, M.; Sbrana, C.; Logi, C. Early processes involved in host recognition by arbuscular mycorrhizal fungi. New Phytol. 1994, 127, 703-709.

71. Giovannetti, M.; Sbrana, C. Meeting a non-host: the behaviour of AM fungi. Mycorrhiza 1998, 8, 123-130.

72. Tamasloukht, M. B.; Séjalon-Delmas, N.; Kluever, A.; Jauneau, A.; Roux, C.; Bécard, G.; Franken, P. Root factors induce mitochondrial-related gene expression and fungal respiration during the developmental switch from asymbiosis to presymbiosis in the arbuscular mycorrhizal fungus Gigaspora rosea. Plant Physiol. 2003, 131, 1468-1478.

73. Tsai, S. M.; Phillips, D. A. Flavonoids released naturally from alfalfa promote development of symbiotic Glomus spores in vitro. Appl. Environ. Microbiol. 1991, 57, 1485-1488.

74. Phillips, D. A.; Tsai, S. M. Flavonoids as plant signals to the rhizosphere microbes. Mycorrhiza 1992, 1, 55-58.

75. Nagahashi, G.; Douds, D. D. Rapid and sensitive bioassay to study signals between root exudates and arbuscular mycorrhizal fungi. Biotechnol. Techniques 1999, 13, 893-897.

76. Nagahashi, G.; Douds, D. D. Action spectrum for the induction of hyphal branches of an arbuscular mycorrhizal fungus: exposure sites versus branching sites. Mycol. Res. 2003, 107, 1075-1082.

77. Akiyama, K.; Hayashi, H. Strigolactones: Chemical signals in fungal symbionts and parasitic weeds in plant roots. Ann. Bot. 2006, 97, 925-931.

78. Vierheilig, H.; Alt-Hug, M.; Engel-Streitwolf, R.; Mäder, P.; Wiemken, A. Studies on the attractional effect of root exudates on hyphal growth of an arbuscular mycorrhizal fungus in a soil compartment-membrane system. Plant Soil 1998, 203, 137-144.

79. Sbrana, C.M.; Giovannetti, M. Chemotropism in the arbuscular mycorrhizal fungus Glomus mosseae. Mycorrhiza 2005, 15, 539-545.

80. Gomez-Roldan, V.; Roux, C.; Girard, D.; Bécard, G.; Puech, V. Strigolactones: Promising plant signals. Plant Signal. Behav. 2007, in press.

81. Vierheilig, H.; Garcia-Garrido, J. M.; Wyss, U.; Piché, Y. Systemic suppression of mycorrhizal colonization of barley roots already colonized by AM fungi. Soil Biol. Biochem. 2000, 32, 589595.

82. Vierheilig, H.; Maier, W.; Wyss, U.; Samson, J.; Strack, D.; Piché, Y. Cyclohexenone derivativeand phosphate-levels in split-root systems and their role in the systemic suppression of mycorrhization in precolonized barley plants. J. Plant Physiol. 2000, 157, 593-599.

83. Catford, J. G.; Staehelin, C.; Lerat, S.; Piché, Y.; Vierheilig, H. Suppression of arbuscular mycorrhizal colonization and nodulation in split-root systems of alfalfa after pre-inoculation and treatment with Nod factors. J. Exp. Bot. 2003, 54, 1481-1487.

84. Vierheilig, H. Further root colonization by arbuscular mycorrhizal fungi in already mycorrhizal plants is suppressed after a critical level of root colonization. J. Plant Physiol. 2004, 161, 339-341. 
85. Meixner, C.; Ludwig-Müller, J.; Miersch, O.; Gresshoff, P.; Staehelin, C.; Vierheilig, H. Lack of mycorrhizal autoregulation and phytohormonal changes in the supernodulating soybean mutant nts1007. Planta 2005, 222, 709-715.

86. Meixner, C.; Vegvari, G.; Ludwig-Müller, J.; Gagnon, H.; Steinkellner, S.; Staehelin, C.; Gresshoff, P.; Vierheilig, H. Two defined alleles of the LRR receptor kinase GmNARK in supernodulating soybean govern differing autoregulation of mycorrhization. Physiol Plantarum 2007, 130, 261-270.

87. Lendzemo, V. W.; Kuyper, T. W. Effects of arbuscular mycorrhizal fungi on damage by Striga hermonthica on two contrasting cultivars of sorghum, Sorghum bicolor. Agr. Ecosyst. Environ. 2001, 87, 29-35.

88. Gworgwor, N. A.; Weber, H. C. Arbuscular mycorrhizal fungi-parasite-host interaction for the control of Striga hermonthica (Del.) Benth. in sorghum [Sorghum bicolor (L.) Moench]. Mycorrhiza 2003, 13, 277-281.

89. Lendzemo, V. W.; Kuyper, T. W.; Kropff, M. J.; van Ast, A. Field inoculation with arbuscular mycorrhizal fungi reduces Striga hermonthica performance on cereal crops and has the potential to contribute to integrated Striga management. Field Crops Res. 2005, 91, 51-61.

90. Lendzemo, V. W. The tripartite interaction between sorghum, Striga hermonthica, and arbuscular mycorrhizal fungi. PhD Thesis, Wageningen University: Wageningen, The Netherlands, 2004.

91. Pinior, A.; Wyss, U.; Piché, Y.; Vierheilig H. Plants colonized by AM fungi regulate further root colonization by AM fungi through altered root exudation. Can. J. Bot. 1999, 77, 891-897.

92. Pinior, A. Wurzelexsudate mykorrhizierter Pflanzen und deren regulierender Einfluss auf arbuskuläre Mykorrhizapilze. Master Thesis, Christian-Albrechts-Universität Kiel: Kiel, Germany, 1999.

93. Yoneyama, K.; Yoneyama, K.; Takeuchi, Y.; Sekimoto, H. Phosphorus deficiency in red clover promotes exudation of orobanchol, the signal for mycorrhizal symbionts and germination stimulant for root parasite. Planta 2007, in press.

94. Yoneyama, K.; Takeuchi, Y.; Yokota, T. Natural germination stimulants for Orobanche minor Sm. In Proceedings of the $7^{\text {th }}$ International Parasitic Weed Symposium; Fer, A.; Thalouarn, P.; Joel, D. M.; Musselman, L. J.; Parker, C.; Verkleij, J. A. C., Eds.; Faculté des Sciences, Université de Nantes: Nantes, France, 2001; p. 123.

95. Nagahashi, G.; Douds, D. D.; Abney, G. D. Phosphorus amendment inhibits hyphal branching of the VAM fungus Gigaspora margarita directly and indirectly through its effect on root exudation. Mycorrhiza, 1996, 6, 403-408.

96. Smith, S.; Read, D. Mycorrhizal symbiosis. Academic Press: London, 1997.

97. Landa, B. B.; Navas-Cortés, J. A.; Castillo P.; Vovlas, N.; Pujadas-Salvà, A. J.; Jiménez- Díaz, R. M. First report of broomrape (Orobanche crenata) infecting lettuce in southern Spain. Plant Disease 2006, 90, 1112.

Samples Availability: Available from the authors.

(c) 2007 by MDPI (http://www.mdpi.org). Reproduction is permitted for noncommercial purposes. 